\title{
THE ‘CELÂLÎEFFECT’ ON RURAL PRODUCTION AND DEMOGRAPHY IN CENTRAL ANATOLIA
}

\author{
THE WAQF OF HATUNIYYE (1590s TO 1638)
}

\author{
KAYHAN ORBAY \\ Department of History, Middle East Technical University \\ Dumlupınar Blvd. No. 1, Çankaya, Ankara 06800, Turkey \\ e-mail: korbay@metu.edu.tr
}

The Celâlî rebel armies ravaged the central Anatolian countryside from the late 16th up to the mid17th century. The Celâlı movements brought about demographic changes and had a long-lasting impact on agricultural economy in some regions. Anatolian waqf institutions being dependent on rural taxpayers and agricultural production for their budgets were seriously harmed by the Celâli rebellions. This paper examines the Celâli effect through the Waqf of Hatuniyye which had villages scattered across central Anatolian districts. The waqf fell into a deep financial crisis and its regular functioning was disrupted in the early 17 th century. The waqf finance was unable to recover for decades after the crisis, which indicates that rural economy in waqf villages suffered from a perpetual production and population crisis.

Key words: rural economy, Central Anatolia, agricultural crisis, Celâlı, waqf, Hatuniyye.

Starting from the last decades of the 20th century, the idea that the Ottoman Empire underwent through a long period of crises and changes in the 16th and 17th centuries has begun to pervade among the historians, and in the new millennium, the crisis and change became a prevailing perspective in historiography. ${ }^{1}$ Ottoman historians developed a criticism towards the decline perception in the works of early generations of Ottoman historians as early as the 1970s and extended their critical reading to the works of 17 th-century contemporary writers, which culminated in the re-evaluation of historical events and authors' reflections on these events, a revision or denial of

${ }^{1}$ For some works explaining the comprehension of these two centuries as a period of stagnation and decline by the contemporaries, their imaginative conception of perfect "Order" or "Golden Age" as the central element in their decline diagnosis and the reproduction of their arguments by early generations of Ottomanists, see Lewis (1962); İnalc1k (1970, pp. 342 ff; 1985, pp. 283-285; 1998); Fleischer (1986); Fodor (1986); Howard (1987, pp. 23-26; 1988); Abou-El-Haj (1991); Woodhead (1995); Öz (1997). 
the golden age notion and the alleged decline concept in the early modern literature. Eventually historians mounted a challenge to the arguments with ideological tuning and produced by modern scholarship in the positivist political history of the early 20th century (Owen 1976; Kafadar 1995). Not only the critical reading of narrative sources, of course, but the influence of literature developed around the 17th century general crisis theory in the West, examining the Ottoman experience in the framework of the world systems theory, the impact on research fields in Ottoman history of Annales school and the vivid debates on price revolution and military revolution inspired new approaches to and research questions for the 16th and 17th centuries (Faroqhi 2010). Fed by vast primary sources from recently reorganised and opened archives, research expanding on varying questions and fields proliferated in Ottoman history. As D. Quataert (2003, p. 3) pointed out "As the field of Ottoman history has developed, so has the critique on the decline paradigm". Thus, the view of crisis and change replaced the previous "stagnation and decline paradigm" which prompted historians to interpret any change or transformation as a sign of dissolution, deterioration, corruption and any conjectural crisis just a phase towards the inevitable ending, the collapse of the Empire. ${ }^{2}$ However, the crisis and change understanding, in turn, developed into a new paradigm and defined a distinct period leaving the previous period largely intact to the periodisation of classical age and the still obscure 18th century to the forthcoming scholarship (Peirce 2004).

Historians began to reveal crises and transformations in real, fiscal and monetary sectors alongside political crises and dramatic demographic changes. In the real sector, a production decline in the urban and rural economy and a contraction in the volume of foreign trade were arguments taken from the decline paradigm but toned down in the new crisis allowing for recovery and survival (Owen 1977; Naff 1977; Quataert 1993; Faroqhi 1994). ${ }^{3}$ The deep fiscal crisis of the state was surmounted by the transformation in fiscal management through adapting taxation and tax collection methods to the recent conditions of financial distress (İnalc1k 1985; Darling 1996, pp. 1-21; 1997). The decline, which has been argued above for the political and military fields, gave birth to new concepts and perspectives in the new approach (Kunt 1983; 1995; Abou-El-Haj 1991; Fodor 1994; Tezcan 2010). The decline of the Empire as a political entity was now the birth of the Second Empire (Tezcan 2010). The Ottoman army was not a victim of but one of the participants in the military revolution, though with some lag in certain technologies (Ágoston 1993; 1994; 2005; Grant 1999; Börekçi 2006; Çalışır 2011). The thesis of demographic catastrophe was rejected or revised, at least for the Balkan provinces (McGowan 1981; Todorova 1988; Todorova-Todorov 1992; Kiel 1990).

\footnotetext{
${ }^{2}$ For the development of the "Modern Approach" or the "Idea of Transformation" in Ottoman historiography, in addition to the works in the previous footnote, see Faroqhi (1995) and Quataert (2003).

${ }^{3}$ The decline of the Bursa silk industry was redefined as conjectural contraction, Cf. the following two authors: Dalsar (1960); Çizakça (1980; 1987). Also see Çizakça (1985) and Gerber (1988).
} 
One of the undisputed and most enduring contentions in both of the paradigms is the agricultural crisis. The crisis in the agricultural sector combined with social unrest and turmoil was defined as the contraction in arable cultivation, the inadequate supply of grain production for sustaining the increasing population, the advance of stockbreeding and pasture at the disadvantage of agricultural land, the dissolution of small family farms and the rise of large market-oriented commercial farmlands (İnalc1k 1985; Akdă̆ 1945; 1995a; 1995b; Güçer 1964; Öz 2000; Özel 2004). The Celâlî rebellions were considered to be the most palatable reason for the agricultural crisis. The adverse effect of climate on agricultural production has been presented in a couple of works (Griswold 1983; 1993; Goldstone 1988; 1991). Furthermore, quite recently, inspired by the rising interest in the debate on the general crisis of the 17 th century, a monograph assigned climate change an essential role in explaining agricultural deterioration (White 2011). Thus, rebellions and climate change were considered primary causes of agricultural crisis while demographic growth and price inflation together with oppression and extortion of local prebend holders, and protracted wars on two fronts were developments affecting agricultural conditions, inciting rebellions and in turn leading to agricultural decline.

The Celâlî effect on agricultural economy was deserted villages, decline in production and price shocks (Akdağ 1945; 1995a; Öz 2000; Özel 2004; 2016). Celâlîs looted and sacked the villages for grain, sheep and goats and other foodstuffs. Peasants having lost their land and harvest were no longer able to cultivate the land and fled to safer places in dread of the Celâlîs (Uluçay 1944; Akdağ 1945; 1995a).

The thesis pertaining to the agricultural crisis and recently supported by the supposed adverse effect of climate change on agricultural production has become a preconception and supplied a framework for the discussion of developments in the early modern Ottoman Empire (White 2011).

The archival sources available to researchers to illuminate the crisis in agriculture are the records of deserted villages, difficulties in tax collection from these villages and the emigrant peasants in the court registers (şeriye sicilleri) and the draft registers of imperial decrees (mühimme defterleri). Survey registers (tahrir defterleri), poll tax registers and later on the avartz registers ${ }^{4}$ have allowed researchers to observe the mass demographic movements and conclude that the agricultural crisis exacerbated as a consequence of population loss (İnalc1k 1965; Özel 1999).

Briefly, the crisis was defined on the basis of demographic data, official corresponding and price series from imperial capital, which were, to a certain extent, employed rather than the economic indicators such as the level of agricultural production, changes in local prices and income collection difficulties by local institutions in the affected regions. Sporadic price data and snapshot views provided by survey and avarı registers from two quite distant years are inadequate to answer questions of the extent and duration of the crisis, how deep it was, and when the agricultural economy recovered.

\footnotetext{
${ }^{4}$ Registers kept for the collection of extraordinary taxes which turned into regular taxes around the turn of the 17 th century.
} 
Monographs on large waqf institutions in Central Anatolia enhance the crisis literature by supplying more detailed data and reliable evidence from the localities, thus allow revealing the actual course of crisis and dating both the crisis and recovery. The Celâli rebellions were major but only one of the developments that affected the agricultural economy. The agricultural and urban economy, particularly at the local level, were exposed to natural hazards and sudden shocks due to various events such as inclement weather, epidemics, earthquakes, fires, and locust invasions. Local monographic studies would assist in discovering the effect of these events and the Celâli effect on the economy.

The waqf account books are one of the most valuable archival sources available to observe local economic developments. These accounts reveal the financial conditions of waqfs, which were interdependent, having a local economy. Therefore, financial analyses of waqf institutions can be used as an indicator of the local economic developments.

Barkan introduced Ottoman historians to the waqf account books (Barkan 1964; 1971a; 1971b; 1971c; see also Orbay 2007a; 2013). However, these archival sources have been largely neglected, although a couple of historians have employed them as primary sources of their work on the local economy of the Ottoman Empire (Faroqhi 1974; 1981; 1988; Orbay 2007b; 2010). The present paper utilises a series of main account books belonging to the Waqf of Hatuniyye in the central Anatolian town of Tokat to analyse the Celâli effect on the waqf in terms of their finance and charitable activities, and on the regional agricultural economy.

The Waqf of Hatuniyye in Tokat founded by Gülbahar Hatun, the mother of Sultan Bayezid II, composed of a medrese, a noble mosque and a public kitchen (imâret), was one of the wealthiest waqfs in 16th-century Anatolia. Not including the money carried forward from the previous year and the accounts receivable, its annual income in any current fiscal year in the late 16th century was around half a million akçe. ${ }^{5}$ Tax revenues of many villages scattered across different districts (kazâ) including those of Çerkeş, Kangırı, Kalecik and Mecidözü were endowed to the waqf. ${ }^{6}$ Hence, the waqf collected income from villages across a vast rural area extending from the east of the town of Çorum, to Çankırı and to the northeast part of Ankara. Having vast agricultural holdings and the waqf budget wholly consisting of rural taxes rendered the waqf an indispensable part of regional agricultural economy.

Taxes on rural population and agricultural production were considered relatively safe and stable sources of income in the traditional economy of the Empire, thus suitable for endowing to a charitable foundation. More importantly, only rural taxes would generate sufficiently large sums to cover immense expenditure of the large imperial waqfs. Therefore, rural revenues were an essential part of the budgets of these waqfs.

\footnotetext{
${ }^{5}$ From the account register of MAD 2076 housed in the "Maliyeden Müdevver" section of the Prime Ministerial Ottoman Archive in İstanbul.

${ }^{6}$ For a full list of villages endowed to the waqf see its endowment deed (vakfiyye) dated A.H. 898 (A.D. 1492) and housed under the call number VGMA:740:405/158 in the archive of the Directorate General of Foundations in Ankara.
} 
Although the size of the harvest and the price of grain fluctuated from year to year in the traditional agricultural economy of central Anatolia, this was hardly noticeable and had no serious negative effect on the waqfs' finance and maintenance of their services and buildings. As many other large imperial waqfs, Hatuniyye was well endowed and achieved a considerable budget surplus in an ordinary year. Thus, the waqf was able to cover all the expenditures and compensate for a mild loss in overall income resulting for instance from a harvest deficiency in a couple of villages. The waqf was even able to absorb financial hardships by resorting to budgetary measures such as suspending salary payments to the waqf staff and the beneficiaries, purchasing on credit, curtailing the amount of stored food or reducing their quality for a lower price. In other words, short-term and relatively modest financial difficulties were overcome by delaying expenditure on certain items until the forthcoming financial year.

Nevertheless, the dependence of the waqf budgets on the agricultural population and their production could drive all these waqfs into financial dire straits and could even harm the daily running of the institution if harvest size and prices showed extreme moves out of the anticipated band of fluctuation. Even today it is difficult to estimate a harvest and the possible prices of agricultural products and in the 16th century agricultural economy, the yield was far more susceptible to weather conditions and diseases. Food prices moved up and down on an annual basis, sometimes sharply, and seasonal volatility was also exhibited. However, these harvest and price fluctuations might not necessarily result in financial distress for the producers and waqfs. In fact, grain prices are negatively correlated with the yield. A harvest failure results in an increase in grain price and, since the demand for grain is highly price-inelastic, the total income of both the farmers and waqfs increase despite a fall in the amount of goods in kind collected in payment for the taxes demanded by the waqfs. However, the peasants would suffer greatly in certain extreme cases such as a complete or nearly complete crop failure due to a severe natural disaster for instance flood or locust invasion. In the event of a complete harvest failure the peasants would have no grain to sell in the market, would not be able to save seed to sow in next season, and total income would definitely decline irrespective of the price of grain in the market. ${ }^{7}$

In addition to natural events, widespread rebellions were another factor that might have led directly or indirectly to a decline in agricultural production. In the last decades of the 16th century, several villages of the Waqf of Hatuniyye were affected by the Celâlî movements. The Celâlî events in the Anatolian provinces of the Ottoman Empire recurred intermittently for more than a half-century left their mark on several spheres and had an effect on many developments of the 16th and 17th centuries which can be conceptualised as the "Celâlî Effect" in the Ottoman "transformation period". The effects of the Celâlî revolts on Ottoman demography had varied facets. In the

\footnotetext{
${ }^{7}$ Nonetheless, in the Ottoman taxation system taxpayer peasants were often not entitled to defer or abate payment but they could be granted full relief from tax liabilities if they could prove that their situation was desperate. Furthermore, if the farmers had no stored seed from the previous season, which was unlikely, or their store was empty since the seed had been consumed or sold in despair, they could easily buy or borrow seed for the next season, thus maintaining the level of the crop yield.
} 
short-term, the revolts led to the depopulation of villages and increased the population of more distant and safer settlements in other provinces caused by many people fleeing from the Celâlîs. Demographic historians maintain that the population decline followed social turmoil and large-scale migrations were a long-term effect of rebellions (Özel 2004; 2016).

In fiercest years of the Celâlî insurrection, large rebel armies laid siege to towns, interrupted the regular course of home and international trade, disrupted the tax collection system, plundered villages and extorted cash and crops from the peasants. Villagers, fearful and desperate, left their farms and fled to the highlands, sheltered in guarded fortifications and migrated to safer villages and towns away from rebels. The period between 1603 and 1608 saw massive migrations, which were referred to as the Great Flight (Büyük Kaçgun) (Akdağ 1945; 1995a).

The decline in agricultural production was primarily due to the migration of the rural population and the disrupted trade network. Not only was the available supply of grain reduced but also the demand decreased in the regions attacked by the Celâli raids. In this case, the prices did not rise rapidly. Since much of the grain had been looted neither the peasants nor the waqfs had grain to sell at high prices at the markets. Furthermore, since the Celâlîs large and small bandit factions roamed the countryside even if the peasants had enough grain to sell they would have had problems in travelling to fairs or markets in order to sell and convert their grain into cash.

The situation might not always have been that difficult for the peasants, since security was not constantly absent at every corner at any moment. Moreover, although the peasants could not sell grain and earn money, they were mostly either exempted from tax or the tax collectors were unable to visit them due to insecurity on the roads.

On the other hand, the large Anatolian waqfs were in a worse situation (Faroqhi 1974; 1987; 1988; Orbay 2004; 2012). These institutions were located in town centers but needed to collect taxes from remote villages and transport them to pantry storage place in the waqf or require the tax farmers to do this. The tax collectors of the central treasury had similar difficulties in undertaking their duty (Darling 1996; Özel 2005; 2011). Two situations drove the waqfs into financial distress. First, there was the difficulty of collecting and delivery of taxes, in kind and cash, to the waqf. The second, and possibly a greater problem, was the loss of a large portion of the cash taxes levied on the population, which could not be collected because many people had left their villages moving to safer provinces.

The situation of the Waqf of Hatuniyye in the early 17 th century can be seen in its account books over these troubled years. The financial well-being of the waqf was intertwined with rural economy and demography, its deteriorating finances in this period is a reflection of the worsening agricultural conditions, social turbulence and depopulation in inner Anatolia. Details from these financial records are given below.

The earliest dated account book of the Hatuniyye available in the Prime Ministerial Archive in İstanbul pertains to the year 1593 (MAD 2076). The book has a regular accounting period covering a full year. The expected income of the waqf from the financial year is about 500,000 akçe. The waqf collected its rural revenues through tax farming and emânet. Tax farming, consisted of one or more villages grouped as 
a tax unit (mukâta' $a$ ) and auctioned to the tax farmer who made the highest bid. The waqf offered two tax-farming units for a total of 95,000 akçe in 1593, each unit consisted of several villages. The remainder of the waqf villages was divided into tax collection regions (cibâyet) composed of several nearby villages. The villages in each of these collection regions were again grouped into tax-farm units and farmed out, sometimes to different tax farmers. However, contrary to the usual practice, only some taxes were farmed out in this manner with the remaining taxes being collected by the emânet method by the salaried tax collectors $(c \hat{b} b \hat{\imath})$ in the waqf staff or the trustees (emin). For instance, çift-tax, taxes from orchards and mills were collected by the collectors and trustees.

Tithe (ösrr) in these tax collection regions was mostly farmed out. It seems that the waqf mostly received the cash equivalent of the tithe from the tax farmers. Only a few portions of the total in-kind tax collection was transferred to the pantry of waqf's kitchen to be used in meals served in the imâret. For each region, the amounts of tithe on wheat and barley were recorded in kile and priced at different levels, and their total worth was also calculated and recorded by the scribe. For instance, wheat was priced from 30 to 60 akçe per kile in 1593. This appears to be a wide price range over a year and may indicate an adverse development in agricultural production. The average price in this year was about 38 akçe per kile, then approximately 33 akçe in 1614 and skyrocketed to 100 akçe in 1615. The latter figure refers to an extreme event. Other examples of extreme prices occurred in the first part of the 17th century; in 1628 wheat price was 100 akçe per kile and about 156 akçe in 1638 while price levels were actually low in general in these decades.

The Waqf of Hatuniyye, as the other dynastic waqfs, was an institution that created a redistributive economy and provided employment. In 1593, the waqf expenditure was around 430,000 akçe of which about 115,000 akçe was paid to 78 waqf employees and 14 stipend holders. Kitchen expenditure was 270,000 akçe of which largest part was spent for meat and wheat purchase, 68,000 and 73,000 akçe respectively. All these outgoings were undertaken within a town economy and supported the economic and commercial activity in that town. The waqf transferred regular income and thus, purchasing power to its employees through salary payments. This redistributive function of the Waqf of Hatuniyye must have been significant for the urban economy and wealth of the relatively small town of Tokat.

The account book of 1593 records no arrears. The waqf was supervised by the central authorities and bound to transfer its budget surplus. After the cash deliveries to the central treasuries, the account was closed with a budget surplus of circa 184,000 akçe which shows that financial situation of the waqf was strong in that year.

An uninterrupted series of account books are available until 1599 which show us pre-Celâli situation. The rural income of the waqf for each year from 1593 to 1599 fluctuated slightly depending mainly on the harvest size and price of various foodstuffs. The total rural income of the waqf declined if the harvest was good and consequently prices were low. For the same reasons kitchen expenditure declined. When harvests fell short, prices went up steeply and the total income increased but so did the kitchen expenses. 
The number of employees and beneficiaries and the amount of salary payments did not change during the period 1593 to 1599 . The waqf did not experience any serious difficulty in tax collection, which implies that the agricultural situation was stable in the tax farming regions. Certainly, the size of the harvest and prices fluctuated from year to year but this had been within the anticipated range in traditional agricultural production. As mentioned above, when annual income was somewhat low, the waqf maintained its budget balance by known methods such as using credit to purchase certain items, delaying salary payments, and reducing the amount of stored food. In this way, the waqf was able to make fulfil its obligations to deliver cash to the central treasuries and sustain a budget surplus at the end of each financial year.

In sum, the Waqf of Hatuniyye in Tokat seems to be in a financially good situation in the last decade of the 16th century before the Celâlîs attacked the region. Although the revenues of the waqf depended on the agricultural production and prices, the effects of harvest fluctuations appeared to have only a moderate impact on the waqf's budget and did not drive the waqf into financial difficulty.

Unfortunately, account books are lacking for the first decade of the 17th century during the time in which the Celâlî rebellions intensified in central Anatolia (Akdağ 1945; 1995a; Griswold 1983). Not only the large Celâlî rebel armies but also several large and small brigand bands were roaming, plundering and spreading terror in Anatolian countryside in these years. ${ }^{8}$ Peasants in fear of their life abandoned land and the large-scale flight, known as the Great Flight took place between the years 1603 and 1608. Demographic historians are unable to give a figure for the size of depopulation within this decade due to the lack of archival sources. However, comparative research using the survey registers of the late 16th century and the detailed (mufassal) avârız registers of the 1640s showed that the population in some districts was reduced by $50 \%, 40 \%$ of rural settlements had disappeared from the tax records, and the overall taxpayer population reduced by 80\% between 1576 and 1642 (Öz 1999; 2000; Ünal 1999; Açıkel 1999; Özel 2004; 2016).

\section{The Celâlî Effect on Waqf's Finance, Population and Agricultural Production}

After a gap of ten years, the account books of the Waqf of Hatuniyye became available again showing that the waqf revenues from 1610 had fallen drastically. It seems that the waqf had already been in financial difficulty before this time, but it is unclear when this occurred. In 1599, the waqf income was about 443,000 akçe and in 1610 this had declined to approximately 119,000 akçe. The most reasonable explanation for this decline is that the waqf lost its rural tax base as the peasants abandoned their villages and fled to safer districts. Since the agricultural population was dispersed

\footnotetext{
${ }^{8}$ Vagrants had already been engaged in brigandage as small bands in the Ottoman countryside, see Uluçay (1944); Cezar (1965); Akdağ (1995a).
} 
and production declined, the waqf was unable to collect any kind of taxes whether in cash or in kind.

The financial deterioration continued as the revenues further declined from the 1610 figure to 78,000 akçe in 1612. Although the waqf income increased in some years, there was no indication of any significant recovery in agricultural production and population. The agricultural crisis as defined in reference to the late 16th century persisted in the waqf villages at least to the late 1630s. It is most likely that the commencement of crisis might be dated to the early years at the turn of the century when the Celâlî armies of Karayazıcı and his brother Deli Hasan plundered and wintered in the villages and towns and imposed their own taxes on the population of the northcentral Anatolian province of Rûm. The rebellious armies of the Celâlı leaders Kalenderoğlu and Abaza Mehmed Pasha visited the region in 1607-1608 and between $1623-1628$, respectively. ${ }^{9}$

The latest dated account book referred to in this paper is from 1638. Neither this account book nor those up to this year give any figures concerning income or expenses, which imply an improvement in the financial condition of the waqf. This means that the "Celâlî effect" on the waqf's finance was quite strong, reducing its annual income by $75 \%$ and it was long lasting. Thus, the waqf was unable to make a financial recovery after the troubled years of the Celâli movements in the early years of the 17th century. It has been assumed that the depopulation in the Celâli period in Anatolia caused a demographic decline in the long term, which showed itself in the waqf's finance and regional agricultural economy for decades.

It is reasonable to suppose that in this period of time, undertaking a tax farm became a risky business for the tax farmers. They either reduced their bids or chose not to bid. Let me remind the reader that the Waqf of Hatuniyye farmed out the collection of taxes from a few tax farming units (mukâta 'a) each consisting of several villages. The waqf continued to engage in tax farming for some villages during the $1610 \mathrm{~s}$ and 1620s. However, the waqf had organised most of its villages under tax collection regions (cibâyet) and a mixed method was used in tax collection. A significant part of the taxes from these regions were collected through the tax farming method while the remainder was collected either by the waqf's tax collectors or by those who undertook the task of tax collection as emin or trustee. In the latter case, differing from the tax-farming method, the trustee did not sign a contract with the waqf for the delivery of a fixed sum to the waqf. He collected and delivered the taxes to the waqf's safe box in return for an amount of money or for a share of the taxes levied.

In 1612 and 1614, for instance, none of the taxes was farmed out in these tax collection regions. All the taxes were collected through the emânet method. This change in the collection method was most likely brought about by the general insecurity in the region, unstable agricultural conditions and unpredictable amount of tax income from production and population.

\footnotetext{
${ }^{9}$ For these Celâlî rebellions and their destructive effects, see Akdağ (1945; 1995a); Griswold (1983); Özel (2016).
} 


\section{The Celâlî Effect on the Functioning of Waqf and the Charitable Activities}

The Waqf of Hatuniyye supported commercial activity and economic development in the town of Tokat. It funneled agricultural revenues into the town economy and transferred purchasing power to a large section of its employees and beneficiaries through salary and stipend payments. When the waqf suffered, a great financial loss due to Celâlîs, its redistributive function and charitable activities were disrupted.

The waqf employed 78 skilled and unskilled persons including learned men such as the müderris, scribes and twelve medrese students. These employees, some of whom had families to support on their salary from the waqf were paid about 100,000 akçe in a year. In addition, though their total number might change from year to year, the waqf was maintained a group of about fifteen beneficiaries who were allocated a monthly payment from the waqf's budget surplus. These beneficiaries were needy people such as the poor, widows without livelihood, and retired waqf officers.

In 1612 , the number of fully paid medrese employees totalling four people and twelve students did not change. However, the twenty employees in the mosque in 1593 were reduced to thirteen in 1612. Accordingly, the salary payment to this group of employees declined from about 16,000 akçe to 12,600 akçe. Surprisingly, the number of Qur'an reciters increased from fifteen to seventeen.

The overall amount of annual salary payments declined between 1593 and 1612 . In addition to the reduction in the mosque staff, the employees in the waqf kitchen declined in number. In 1593, the waqf had employed twenty people including the trustee (mütevelli) and his scribe who, in total, were paid about 35,000 akçe per year. Their number declined to only six persons who were paid approximately 22,000 akçe. ${ }^{10}$ In fact, the public kitchen (imâret) was not operating in this period and in the account books of 1610 and 1612 there is no record of any expenditure for the kitchen.

A storehouse account pertaining to 1593 shows that the waqf was serving flat bread (fodula) daily, soup every morning and night during Ramadan, dâne $e^{11}$ and zerde $^{12}$ on Fridays and nights in Ramadan. The total amount of kitchen expenditure was about 270,000 akçe in 1593. In the accounting period of 1614 , covering about nine months, some expenditure records for the kitchen reappeared. However, the total amount was only 5,820 akçe. This means that the kitchen was not serving meals except maybe for a limited number of waqf employees and the needy. There are also records showing that the waqf was also serving meal to guests but fewer in number than previously.

The account books record quite different levels for the kitchen expenditures in certain years until 1638 with no kitchen expenditures being recorded in various annual periods. In 1615, the waqf spent approximately 30,000 akçe for food for the

\footnotetext{
${ }^{10}$ The storekeeper was not paid his salary, see MAD 2076.

${ }^{11}$ Rice dish with meat.

${ }^{12}$ A dessert made with rice, saffron and starch.
} 
kitchen. In 1619-1620, the expenses for the kitchen were 26,410 akçe, 21,234 akçe of which was for food bought on credit. In 1632, the waqf kitchen expenditure was 12,000 akçe and about 23,000 akçe in 1638. Considering that, the kitchen expenditure was always over 200,000 akçe in any year from 1593 to 1598 these figures imply that the kitchen was not operating at full capacity or regularly during these years.

In 1619-1620, the salary and stipend payments were approximately 122,000 akçe, but only 27,640 akçe was actually paid with 94,800 akçe remaining unpaid (nâresîd). However, it is likely that the waqf made the payments in the following years. The waqf was on the edge of financial crisis each year having lost great part of its revenue due to the activities of the Celâlis. It seems that the waqf tried to adapt to the new financial circumstances by prioritising expenditure on repairs and some salary payments. In 1624, for instance, the waqf did not allocate any money for the kitchen and spent almost all its revenue on salary and stipend payments amounting to 131,000 akçe.

The financial collapse of the waqf affected the beneficiaries more than any other group of waqf employees. There were 14 beneficiaries registered in 1593 who were paid about 20,000 akçe. Their numbers fluctuated over years as new people became entitled to receive a monthly allowance and others died; however, after the waqf's finances were ruined by the Celâlis, the number of beneficiaries was radically reduced to two in 1610 or possibly earlier. A note written at the end of the 1610 account book commenting that the distribution of budget surplus to waqf beneficiaries was forbidden by an imperial decree (fermân) until the waqf's financial situation improved.

To summarise, the waqf was compelled to cease a few of its most crucial charitable functions. It closed a public kitchen or operated it at very low capacity only to serve meals to a few people and guests. Beneficiaries were no longer paid except for those who most gravely needed the monthly payment. The waqf was regularly sending 200 gold pieces, the equivalent of 24,000 akçe to the Holy Places as stipulated in its endowment deed. Since the overall waqf income was substantially reduced, the waqf no longer had any significant surplus. In this situation, the waqf was operating in almost permanent financial distress; thus, it was unable to send the amounts of money to the Holy Places as it did previously.

\section{Conclusion}

The Waqf of Hatuniyye was a wealthy institution in the late 16th century. It operated a public kitchen, regularly paid the salaries of the staff, performed the other services stipulated in its foundation charter and achieved a budget surplus. However, its fortune radically changed from the first decade of the 17th century onwards during which time large numbers of the Celâlî rebels disrupted agricultural production and caused population dispersal. The rebel armies of Karayazıc1, Deli Hasan, Tavil Ahmed, Abaza Mehmed and many other less-famous rebel leaders ravaged the central Anatolian provinces. Since the Waqf of Hatuniyye was dependent solely on rural taxes, the 
Celâlîs inflicted a serious loss on the waqf and it was unable to recover from the financial collapse for decades until at least the mid-17th century.

The decline in agricultural production and ensuing financial crisis of the waqf was long lasting because of various reasons. Firstly, the large rebel armies occupied the region for quite a long time sometimes wintering in central Anatolia. Secondly, for decades different Celâli armies attacked and looted settlements in the countryside one after the other. Their lasting negative impact on agricultural production stemmed from depopulation, which was the chief reason for the long-term decline in agricultural production and the erosion of the waqf's tax base.

The agricultural conditions in the waqf villages and the consequential decline in the financial capacity of the waqf did not allow it to undertake charitable services as it did before the Celâli rebellions. The waqf allocated its reduced budget to salary payments and to the upkeep of buildings. However, there was not enough financial support to keep the kitchen open and to send money to the Holy Places.

\section{Bibliography}

Abou-El-Haj, Rifa'at 'Ali (1991): Formation of the Modern State; The Ottoman Empire Sixteenth to Eighteenth Centuries. Albany, State University of New York Press.

Açıkel, Ali (1999): Changes in Settlement Patterns, Population and Society in North Central Anatolia: A Case Study of the District (Kaza) of Tokat (1574-1643). Unpublished Ph.D. Thesis. University of Manchester, Department of Middle Eastern Studies.

Akdağ, Mustafa (1945): Celali İsyanlarının Başlaması. A. Ü. Dil ve Tarih-Coğrafya Fakültesi Dergisi Vol. 4, No. 1, pp. 23-37.

Akdağ, Mustafa (1995a): Türk Halkının Dirlik ve Düzenlik Kavgası, Celali Ísyanları. İstanbul, Cem Yayınevi.

Akdağ, Mustafa (1995b): Türkiyenin İktisadi ve İçtimai Tarihi 2 (1453-1559). İstanbul, Cem Yay1nevi.

Ágoston, Gábor (1993): Gunpowder for the Sultan’s Army. Turcica Vol. 25, pp. 75-96.

Ágoston, Gábor (1994): Ottoman Artillery and European Military Technology in the Fifteenth and Seventeenth Centuries. $A O H$ Vol. 47, Nos 1-2, pp. 15-48.

Ágoston, Gábor (2005): Guns for the Sultan; Military Power and the Weapons Industry in the Ottoman Empire. New York, Cambridge University Press.

Barkan, Ömer Lütfi (1964): Edirne ve Civarındaki Bazı İmaret Tesislerinin Yıllık Muhasebe Bilançoları. Türk Tarih Belgeleri Dergisi Vol. I, No. 2, pp. 235-377.

Barkan, Ömer Lütfi (1971a): Süleymaniye Cami ve İmareti Tesislerine Ait Y1llık Bir Muhasebe Bilançosu 993/994 (1585/1586). Vakıflar Dergisi No. 9, pp. 109-161.

Barkan, Ömer Lütfi (1971b): Fatih Cami ve İmareti Tesislerinin 1489-1490 Yıllarına ait Muhasebe Bilançoları. Vakıflar Dergisi No. 9, pp. 297-341.

Barkan, Ömer Lütfi (1971c): Ayasofya Cami'i ve Eyüb Türbesinin 1489-1491 yıllarına ait Muhasebe Bilançoları. Vakıflar Dergisi No. 9, pp. 342-379.

Börekçi, Günhan (2006): A Contribution to the Military Revolution Debate: The Janissaries' Use of Volley Fire during the Long Ottoman-Habsburg War of 1593-1606 and the Problem of Origins. $A O H$ Vol. 59, No. 4, pp. 407-438.

Cezar, Mustafa (1965): Osmanlı Tarihinde Levendler. İstanbul, İstanbul Güzel Sanatlar Akademisi Yayınları. 
Çalışır, M. Fatih (2011): Decline of a "Myth": Perspectives of the Ottoman "Decline". The History School No. 9, pp. 37-60.

Çizakça, Murat (1980): A Short History of the Bursa Silk Industry (1500-1900). Journal of the Economic and Social History of the Orient Vol. 23, Nos 1-2, pp. 142-152.

Çizakça, Murat (1985): Incorporation of the Middle East into the European World Economy. Review Vol. 8, No. 3, pp. 353-378.

Çizakça, Murat (1987): Price History and the Bursa Silk Industry: A Study in Ottoman Industrial Decline, 1550-1650. In: İslamoğlu-İnan, Huri (ed.): The Ottoman Empire and the WorldEconomy. New York, Cambridge University Press, pp. 247-261.

Dalsar, Fahri (1960): Bursa'da İpekçilik. İstanbul, Sermet Matbaası.

Darling, Linda (1996): Revenue-Raising and Legitimacy; Tax Collection and Finance Administration in the Otoman Empire 1560-1660. Leiden, E. J. Brill.

Darling, Linda (1997): Ottoman Fiscal Administration: Decline or Adaptation? The Journal of European Economic History Vol. 26, No. 1, pp. 157-179.

Faroqhi, Suraiya (1974): Vakıf Administration in Sixteenth Century Konya, The Zaviye of Sadreddin-i Konevi. JESHO Vol. 17, No. 2, pp. 145-172.

Faroqhi, Suraiya (1981): Seyyid Gazi Revisited: The Foundation as Seen Through Sixteenth and Seventeenth-Century Documents. Turcica Vol. 13, pp. 90-121.

Faroqhi, Suraiya (1987): A Great Foundation in Difficulties: or Some Evidence on Economic Contraction in the Ottoman Empire of the Mid-seventeenth Century. Revue D'Histoire Magrebine Nos 47-48, pp. 109-121.

Faroqhi, Suraiya (1988): Agricultural Crisis and the Art of Flute-Playing: The Worldly Affairs of the Mevlevi Dervishes (1595-1652). Turcica Vol. 20, pp. 43-69.

Faroqhi, Suraiya (1994): Crisis and Change, 1590-1699. In: İnalcık, Halil-Quataert, Donald (eds): An Economic and Social History of the Ottoman Empire, 1300-1914. New York, Cambridge University Press, pp. 413-636.

Faroqhi, Suraiya (1995): Politics and Socio-economic Change in the Ottoman Empire of the Later Sixteenth Century. In: Kunt, Metin-Woodhead, Christine (eds): Süleyman the Magnificent and His Age. New York, Longman, pp. 91-113.

Faroqhi, Suraiya (2010): Empires before and after the Post-colonial Turn: The Ottomans. In: Quataert, Donald-Tezcan, Baki (eds): Beyond Dominant Paradigms in Ottoman and Middle Eastern/ North African Studies: A Tribute to Rifa'at Abou-El-Haj. İstanbul, İSAM, pp. 57-76.

Fleischer, H. Cornell (1986): Bureaucrat and Intellectual in the Ottoman Empire: The Historian Mustfa Ali, 1541-1600. Princeton, Princeton University Press.

Fodor, Pál (1986): State and Society, Crisis and Reform. AOH Vol. 40, pp. 217-240.

Fodor, Pál (1994): Sultan, Imperial Council, Grand Vizier: Changes in the Ottoman Ruling Elite and the Formation of the Grand Vizieral Telhịs. $A O H$ Vol. 47, Nos 1-2, pp. 67-85.

Gerber, Haim (1988): Economy and Society in an Ottoman City: Bursa, 1600-1700. Jerusalem, The Hebrew University.

Goldstone, Jack (1988): East and West in the Seventeenth Century: Political Crises in Stuart England, Ottoman Turkey, and Ming China. Comparative Studies in Society and History Vol. 30, No. 1, pp. 103-142.

Goldstone, Jack (1991): Revolution and Rebellion in the Early Modern World. Berkeley, University of California Press.

Grant, Jonathan (1999): Rethinking the Ottoman 'Decline': Military Technology Diffusion in the Ottoman Empire, Fifteenth to Eighteenth Centuries. Journal of World History Vol. 10, No. 1, pp. 179-201. 
Griswold, J. William (1983): The Great Anatolian Rebellion 100-1020 / 1591-1611. Berlin, Klaus Schwarz.

Griswold, J. William (1993): Climatic Change: A Possible Factor in the Social Unrest of Seventeenth Century Anatolia. In: Lowry, Heath W.-Quataert, Donald (eds): Humanist and Scholar, Essays in Honor of Andreas Tietze. İstanbul, The Isis Press and the Institute of Turkish Studies, pp. 37-57.

Güçer, Lütfi (1964): XVI-XVII. Asırlarda Osmanlı Imparatorluğunda Hububat Meselesi ve Hububattan Alınan Vergiler. İstanbul, İ.Ü. Yayımlarından.

Howard, A. Douglas (1987): The Ottoman Timar System and Its Transformation, 1563-1656, unpublished Ph.D. thesis, Indiana University.

Howard, A. Douglas (1988): Ottoman Historiography and the Literature of "Decline" of the Sixteenth and Seventeenth Centuries. JAH Vol. 22, No. 1, pp. 52-77.

İnalcık, Halil (1965): Adaletnameler. Belgeler Vol. II, Nos 3-4, pp. 49-145.

İnalckk, Halil (1970): The Heyday and Decline of the Ottoman Empire. In: Holt, P. M. - Lambton, Ann K. S.-Lewis, Bernard (eds): The Cambridge History of Islam, Vol. 1, The Central Islamic Lands. London, Cambridge University, pp. 324-353.

İnalc1k, Halil (1985): Military and Fiscal Transformation in the Ottoman Empire, 1600-1700. In: Studies in Ottoman Social and Economic History. London, Variorum Reprints, pp. 283337.

İnalcık, Halil (1998): Periods in Ottoman History. In: Essays in Ottoman History. İstanbul, Eren, pp. $15-28$.

Kafadar, Cemal (1995): The Myth of the Golden Age: Ottoman Historical Consciousness in the Post-Süleymanic Era. In: İnalcık, Halil-Kafadar, Cemal (eds): Süleyman the Second and His Time. İstanbul, Isis, pp. 45-57.

Kiel, Machiel (1990): Remarks on the Administration of the Poll Tax (Cizye) in the Ottoman Balkans and Value of Poll Tax Registers (Cizye Defterleri) for Demographic Research. Etudes Balkaniques Vol. 26, No. 4, pp. 70-104.

Kunt, Metin (1983): The Sultan's Servants, The Transformation of Ottoman Provincial Government, 1550-1650. New York, Cambridge University Press.

Kunt, Metin (1995): State and Sultan up to the Age of Süleyman: Frontier Principality to World Empire. In: Kunt, Metin -Woodhead, Christine (eds): Süleyman the Magnificent and His Age. New York, Longman, pp. 3-29.

Lewis, Bernard (1962): Ottoman Observers of Ottoman Decline. Islamic Studies Vol. 1, No. 1, pp. $71-87$.

McGowan, Bruce (1981): Economic Life in the Ottoman Europe; Taxation, Trade and the Struggle for Land, 1600-1800. Cambridge, Cambridge University Press.

Naff, Thomas (1977): Introduction. In: Naff, Thomas-Owen, Roger (eds): Studies in Eighteenth Century Islamic History. Carbondale and Edwardsville, Southern Illinois University Press, pp. 3-14.

Orbay, Kayhan (2004): Celalis Recorded in the Account Books. Rivista degli Studi Orientali Vol. 78, Nos 1-2, pp. 71-84.

Orbay, Kayhan (2007a): Structure and the Content of the Waqf Account Books as Sources for Ottoman Economic and Institutional History. Turcica Vol. 39, pp. 3-48.

Orbay, Kayhan (2007b): 16. ve 17. Yüzyıllarda Bursa Ekonomisi: Sultan Çelebi Mehmed Yeşil İmaret'inin Mali Tarihi (1553-1650). A.Ü. Osmanlı Tarihi Araştırma ve Uygulama Merkezi (OTAM) Dergisi No. 22, pp. 125-158. 
Orbay, Kayhan (2010): The Waqf of Saruca Pasha in Gallipoli and Agricultural Economy in 17thCentury Thrace. A.Ü. Osmanl Tarihi Araştırma ve Uygulama Merkezi (OTAM) Dergisi No. 27, pp. $143-163$.

Orbay, Kayhan (2012): Financial Development of the Waqfs in Konya and the Agricultural Economy in the Central Anatolia (Late Sixteenth - Early Seventeenth Centuries). JESHO Vol. 55, No. 1, pp. 74-116.

Orbay, Kayhan (2013): Account Books of the Imperial WAQFS (Charitable Endowments) in the Eastern Mediterranean (15th to 19th Centuries). Accounting Historians Journal Vol. 40, No. 1, pp. 31-50.

Owen, Roger (1976): The Middle East in the Eighteenth Century: An 'Islamic' Society in Decline? A Critique of Gibb and Bowen's Islamic Society and the West. Bulletin (British Society for Middle Eastern Studies) Vol. 3, No. 2, pp. 110-117.

Owen, Roger (1977): Introduction. In: Naff, Thomas-Owen, Roger (eds): Studies in Eighteenth Century Islamic History. Carbondale and Edwardsville, Southern Illinois University Press, pp. 133-151.

Öz, Mehmet (1997): Osmanlı'da Çözülme ve Gelenekçi Yorumcuları. İstanbul, Dergah.

Öz, Mehmet (1999): Bozok Sancağı'nda İskan ve Nüfus (1539-1642). In: XII. Türk Tarih Kongresi. Ankara, Türk Tarih Kurumu, pp. 787-794.

Öz, Mehmet (2000): XV.-XVI. Yüzyıllarda Canik Sancağı. Ankara, Türk Tarih Kurumu.

Özel, Oktay (1999): 17. Yüzyıl Osmanlı Demografi ve İskan Tarihi İçin Önemli Bir Kaynak: 'Mufassal' Avartz Defterleri. In: XII. Türk Tarih Kongresi, 12-16 Eylül 1994, Kongreye Sunulan Bildiriler, Vol. III. Ankara, Türk Tarih Kurumu, pp. 735-743.

Özel, Oktay (2004): Population Changes in Ottoman Anatolia during the 16th and 17th Centuries: The "Demographic Crisis" Reconsidered. International Journal of Middle East Studies Vol. 36, No. 2, pp. 181-205.

Özel, Oktay (2005): Banditry, State and Economy: On the Financial Impact of the Celali Movement in Ottoman Anatolia. In: İnalc1k, Halil-Özel, Oktay (eds): IXth Congress of Economic and Social History of Turkey. Ankara, Türk Tarih Kurumu, pp. 65-74.

Özel, Oktay (2011): The Reign of Violence: the Celalis, c.1550-1700. In: Woodhead, Christine (ed.): The Ottoman World. London-New York, Routledge, pp. 184-202.

Özel, Oktay (2016): The Collapse of Rural Order in Ottoman Anatolia, Amasya 1576-1643. Leiden, Brill.

Peirce, Leslie (2004): Changing Perceptions of the Ottoman Empire: The Early Centuries. Mediterranean Historical Review Vol. 19, No. 1, pp. 6-28.

Quataert, Donald (1993): Ottoman Manufacturing in the Age of the Industrial Revolution. Cambridge, Cambridge University.

Quataert, Donald (2003): Ottoman History Writing and Changing Attitudes Towards the Notion of "Decline". History Compass Vol. 1, No. 1, pp. 1-9.

Tezcan, Baki (2010): The Second Ottoman Empire: The Political and Social Transformation in the Early Modern World. Cambridge, Cambridge University Press.

Todorova, N. Maria (1988): Was There a Demographic Crisis in the Ottoman Empire in the Seventeenth Century? Etudes Balkaniques Vol. 24, No. 2, pp. 55-63.

Todorova, Maria - Todorov, Nikolai (1992): The Historical Demography of the Ottoman Empire: Problems and Tasks. In: Spence, Richard B. - Nelson, Linda L. (eds): Scholar, Patriot, Mentor: Historical Essays in Honor of Dimitrije Djordjevic. Boulder, East Eropean Monographs, pp. $151-172$.

Uluçay, Çağatay (1944): XVII. Asırda Saruhan'da Eşkiyalık ve Halk Hareketleri. İstanbul, Manisa Halkevi Yayınlarından. 
Ünal, Mehmet Ali (1999): XVI. Yüzyılda Çemişgezek Sancağı. Ankara, Türk Tarih Kurumu.

White, Sam (2011): The Climate of Rebellion in the Early Modern Ottoman Empire. New York, Cambridge University Press.

Woodhead, Christine (1995): Perspectives on Süleyman. In: Kunt, Metin-Woodhead, Christine (eds): Süleyman the Magnificent and His Age. New York, Longman, pp. 164-190. 